\title{
Do Consumers' Ethical Judgments Matter for Purchase Intentions in Online Gray Markets?
}

\author{
Naveen Gudigantala \\ University of Portland \\ Pelin Bicen \\ Suffolk University
}

Gray market goods are genuine goods sourced in an unauthorized manner from a distribution channel and sold at lower prices in different markets. Due to its unauthorized nature, gray marketers use authorized firms' reputable brand identities to make profits without investing the capital associated with establishing market demand and such identities. We investigate consumers' ethical decision making and purchase intention when they are confronted with a choice to purchase from either a gray market retailer or genuine retailer under various financial risk scenarios. Results reveal that consumers predominantly use deontological evaluations (e.g., rightness of the act) to form their judgment rather than whether they gain something positive (e.g., savings) in the exchange. Importantly, we also found that trust fully mediates the relationship between ethical judgment and purchase intention. The current study provides several implications and recommendations to online retailers and consumers.

Keywords: Gray Markets, Ethical Judgments, Hunt-Vitell theory, Purchase Intention, Trust

\section{INTRODUCTION}

Firms around the world confront increasing pressures with the trade of their branded products in unauthorized distribution channels known as gray markets (Ahmadi, Iravani, \& Mamani, 2015). Gray markets are mostly caused by price differentials which may stem from exchange rate fluctuations, brand owners' multi-tiered pricing schemes, tax differences, or differing consumer preferences. Unlike counterfeits, gray market products are genuine in that they have been manufactured by or for, or are under license from, the brand owner (Galstian, 2000).

Billions of dollars' worth of products are diverted into gray markets every year, and, as a result, firms suffer substantial losses in profits. In the IT industry alone, the gray market activities were worth of $\$ 58$ billion worldwide, with IT firms suffering losses in profits up to $\$ 10$ billion (AGMA, 2008). In a followup study by KPMG and AGMA, 63 percent of the OEMs have reported an increase in gray market activity since 2008 (AGMA, 2016). In consumer goods, for example, the head of the watch division of LMVH described gray markets as "industry's cancer" (Koltrowitz, 2017). In the U.K., gray market goods are so popular that people travel to the Netherlands to purchase automobiles at lower prices (Galstian, 
2000). Unfortunately, gray market imports are endemic across a wide variety of industries, ranging from personal computers, heavy construction equipment, and prescription drugs (Gudigantala \& Bicen, 2011).

Unsurprisingly, gray markets create an array of problems for companies and consumers. Companies invest a considerable amount of time, money, and effort in R\&D, manufacturing, quality inspections, customer service, and promoting the goodwill of their products, which reflects in selling prices. Gray marketers free ride on the trademark owner's goodwill and take advantage of the market demand and reputation created and maintained by these companies and their authorized channel partners without investing the capital (Tan, Lim, \& Lee, 1997). Gray markets reduce both the number and quality of goods introduced in markets and also the incentives for firms to develop export markets (Antia et al., 2006; Myers \& Griffith, 1999). Additionally, gray markets erode consumer goodwill because a product meant for a different market varies from the same product designed for domestic consumption in a variety of ways such as health and safety codes, regional tastes, and warranties. Goodwill is further damaged when brand owners refuse to honor gray market products' warranties and create a consumer perception of substandard customer service (Friedman, 1998). Companies also suffer when gray markets disrupt global marketing efforts, causing difficulty in developing and maintaining global image (Chen, 2007). Considering the enormity of problems generated by gray marketers and their use of genuine goods and authorized firms' identities to make profits, it is appropriate to discuss its ethicality (e.g., Huang, 2004; Mathur, 1995).

An online environment has fueled the growth of gray market activities due to the Internet's ease of use, accessibility, and ability to connect consumers with suppliers worldwide (Galstian, 2000). Amazon, eBay, Alibaba, Kmart, and Costco are among the online retailers known to have sold gray market goods (Ahmadi, Iravani, \& Mamani, 2015). Given that online purchase activities have experienced a drastic increase over the years, many non-profit organizations such as AGMA (Alliance for Gray Market and Counterfeit Abatement) and BBB (Better Business Bureau), and popular press such as Forbes, Fortune, and the Economist are shedding light on gray markets and educating consumers about the pitfalls of gray market purchases and their cost to economies (Berman \& Dong, 2016).

Most of the gray market literature has focused on the legal (e.g., Mittal, 2017) and economic aspects of the gray market goods (e.g, Altug, 2017; Iravani, Dasu \& Ahmadi, 2016). However, given the questionable ethical nature of gray market activities, it is interesting that there continues to be a dearth of empirical research on whether consumers' ethical judgements have any influence on their intention to purchase gray market goods.

The literature provides some hints on the consumers' moral attitudes having important implications for their behavior in general (Creyer, 1997; Tan, 2002; Thygersen, 1999). But, the findings are still mixed (Belk, Devinney \& Ekhardt, 2005; Carrigan \& Attalla, 2001). Therefore, not only do we believe it is a fertile area to further our understanding regarding consumer ethics, but it is also relevant and timely to study consumers' ethical decision making in the context of gray market goods.

In this paper, we investigate consumers' ethical decision making when confronted with a choice to purchase from either a gray market retailer or genuine retailer under various financial risk scenarios. We explore consumer perceptions about the ethicality of retailers' sourcing behavior and whether their ethical judgments as a result have an influence on their purchase intention in an online shopping context. Since trust plays a distinct role in reducing the uncertainty and complexity of transactions in online environments, we further explore the role of trust in this dynamic relationship. We draw on the HuntVitell $(\mathrm{H}-\mathrm{V})$ theory of ethics to explain the hypothesized relationships in our conceptual model (Hunt and Vitell 2006) (see Figure 1). We test the hypothesized relationships in an experimental study with 114 subjects.

Our study makes several contributions to the literature on consumer ethical decision-making, gray markets, and online shopping. First, we extend the H-V theory of ethics by incorporating a link between ethical judgment and trust. We show that ethical judgments influence purchase intentions only through trust. Second, to the best of our knowledge, this is the first empirical work that explores how consumers judge the ethicality of gray market activities in an online purchasing context. Findings show that consumers judge gray market activity as unethical, and such perceptions result in lower trust and purchase 
intention concerning gray market retailers. Results also support the main findings of the H-V theory, which postulates that consumers do care about firms' ethical business conduct. Third, our findings shed light on how consumers build trust and purchase intentions when an ethical issue plays a central role in an online purchase context.

\section{FIGURE 1}

\section{THEORETICAL MODEL}

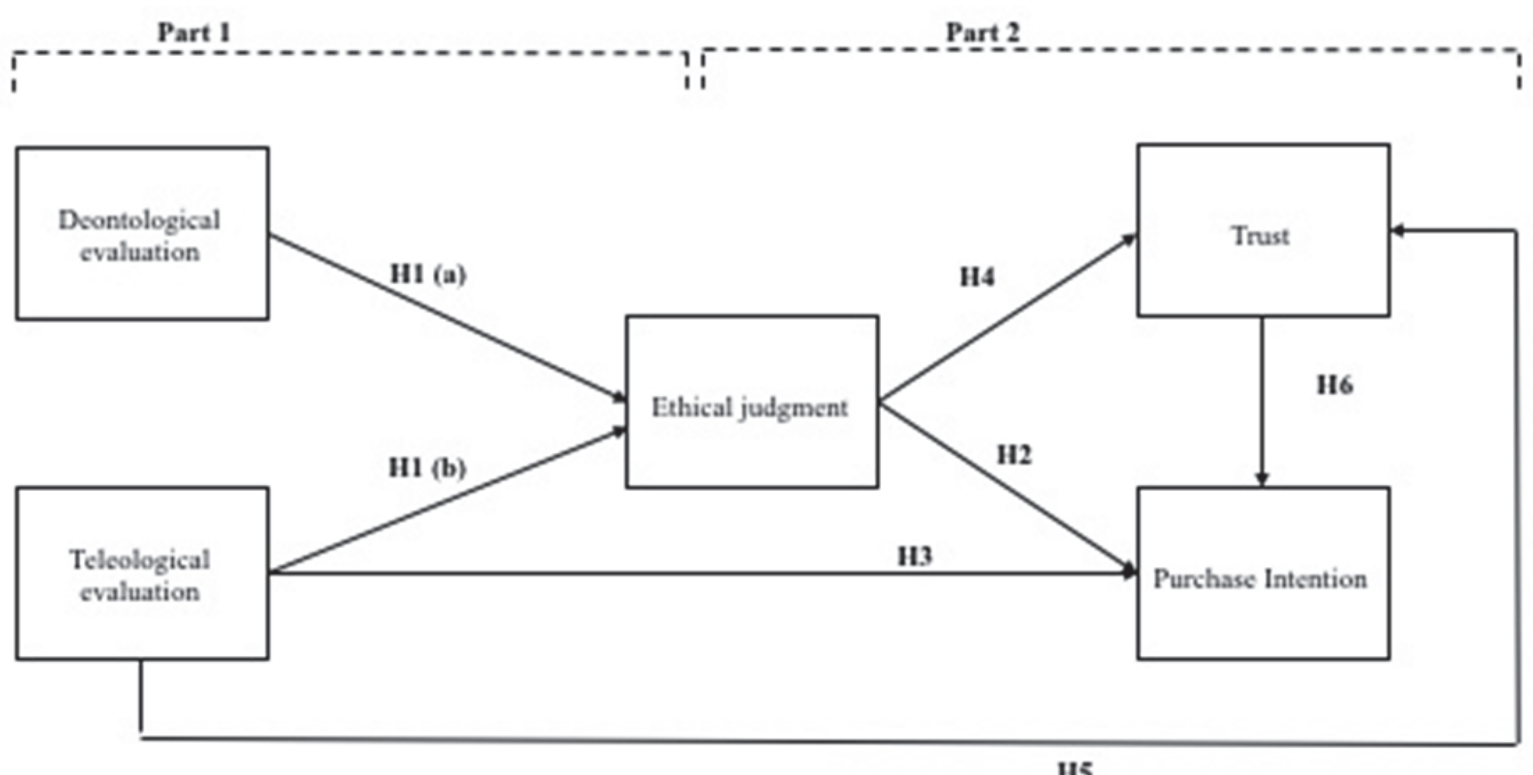

H5

Note: Part 1 of the model (HIa and H1b) tested with the regression analysis. Part 2 of the model H2, H3, H4, H5, and H6 tested with the PLS analysis.

\section{THEORETICAL BACKGROUND}

We draw on the H-V theory of ethics, which is a general theory of ethical decision making developed from the foundations of moral philosophy, to explain our rationale behind the hypotheses (Hunt \& Vitell, 2006). A majority of normative ethical theories can be categorized into either deontological or teleological theories. The H-V theory of ethics hypothesizes consumers' deontological and teleological evaluations as antecedents to their ethical judgement.

The $\mathrm{H}-\mathrm{V}$ model addresses the situation in which an individual confronts a problem perceived as having an ethical content. Once an individual is cognizant of an ethical issue, various possible actions might be taken to resolve the issue. As Hunt and Vitell $(1986 ; 2006)$ state, it is unlikely that an individual will recognize the complete set of possible actions, and therefore, she will only choose from a subset of the universal potential of alternatives. The scope of this study is confined to situations in which consumers are aware of the gray market sourcing of the goods and perceive the situation as having an ethical content.

According to the $\mathrm{H}-\mathrm{V}$ theory, once the individual perceives the evoked set of alternatives, two kinds of evaluations take place: deontological and teleological. The deontological evaluation concerns the individual evaluation of the inherent rightness or wrongness of the behaviors generated from each alternative. In doing so, an individual compares the behaviors with a set of deontological norms (e.g., hypernorms and local norms of the integrative social contract theory), representing an individual's values or moral rules. In contrast, teleological evaluation concerns consequences based on beliefs about the relative goodness versus badness brought about by each alternative, as perceived by the decision maker. The information processing rules will differ across different people's moral codes. In other words, an 
individual will consider a particular action as ethical if it brings greater positive consequences in relation to the amount of negative consequences overall.

The H-V theory postulates that an individual's ethical judgment is a function of both the individual's deontological and teleological evaluation. The theory proposes that ethical judgment and actual behaviors sometimes differ from intentions because teleological evaluations also independently affect intentions (see Figure 1).

Applying the theory in the context of gray market sourcing, when a consumer becomes aware of the gray market sourcing of an online retailer, due to it is being operating in an unauthorized manner and attempting to make profits without investing the capital associated with establishing market demand and brand reputation, she may judge the behavior of a gray market retailer to be unethical. However, it is also possible for her to judge the retailer to be ethical by invoking teleological evaluation. The judgment of ethicality in this context is based on the perception of positive consequences accruing to her because she is able to purchase a genuine product at a lower price. The $\mathrm{H}-\mathrm{V}$ theory recognizes that some individuals in some cases might act as strict deontologists or teleologists, but it also theorizes that such a situation is unlikely to occur with most individuals (Hunt \& Vitell, 1986).

\section{H1: (a) Deontological and (b) teleological evaluations positively influence ethical judgments.}

$\mathrm{H}-\mathrm{V}$ theory also proposed that the intention to implement a particular alternative is a function of ethical judgment and teleological evaluation. Applying this formulation in the context of gray market products, a consumer may judge an online retailer to be unethical and hence form an intention not to buy from the website, or vice versa. Or, in some situations, an individual may perceive a particular alternative as the most ethical, but the person may intend to choose another alternative because of certain preferred consequences (e.g., being able to financially afford a desired item). Thus, teleological evaluation may change a person's intention even though the ethical judgment says otherwise.

A number of studies have tested the aforementioned hypotheses, but in contexts other than gray market sourcing. For example, Vitell, Singhapakdi, and Thomas (2001) examined ethics in consumer purchase behavior in a store by investigating the extent to which consumers rely on ethical norms versus perceived consequences of behaviors. They found that consumers primarily relied on ethical norms and to a lesser degree on perceived consequences in establishing ethical judgments. They also found that there is a significant positive relationship between ethical judgments and behavioral intentions. Similarly, we argue that individuals will incorporate not only their ethical judgments, but also their evaluations on other alternative options, which may have positive consequences in forming their purchase intentions in a gray market context.

\section{H2: Ethical judgment positively influences purchase intention.}

\section{H3: Teleological evaluation positively influences purchase intention.}

Another important factor to consider in online retail is trust. In e-commerce, it is hard to judge the quality of goods, especially if it is from an unfamiliar merchant. A greater degree of trust is needed when shopping online as opposed to buying from a brick and mortar store (Keen, 2000). We define trust as the consumer's belief that the online merchant will not behave in an opportunistic manner (Hong \& Cha, 2013).

We argue that consumers' ethical judgment influences trust. Hunt and Vitell (2006) posit that a consumer's ethical judgment is a function of both whether the retailer behaves ethically in relation to universal norms and whether there are greater positive consequences compared to the amount of negative consequences in a consumer's transaction with the retailer. Once a consumer makes a positive assessment of the ethical business conduct of a retailer, she will have the belief that the online retailer will honor its commitment and act in the best interests of its consumers (Caldwell \& Clapham 2003). Commitment to 
honoring the intent of the relationship and acting in the best interest of the other party are critical factors in building trust (Gullett et al., 2009).

\section{H4: Ethical judgment positively influences trust in an online retailer.}

Consumer behavior, in general, involves risk such that any action of a consumer will lead to unforeseen or possibly unpleasant consequences (Bauer, 1960). The consumer perceives a situation as bearing risk if entering this situation might lead to negative consequences and/or if she feels unable to control the occurrence of these consequences. The uncertainty she perceives with regard to the choice of a product, brand, or retailer determines the nature of the risk. Types of perceived risk can be financial, performance, psychological and/or social risks (e.g., Stone \& Gronhaug, 1993).

In theorizing the influence of consumers' teleological evaluation on trust, we consider the consequences faced by consumers with respect to financial risk. We hypothesize that lower financial risk is associated with higher levels of trust. Although some studies have focused on the effects of trust on perceived risk (e.g., Pavlou, 2003), some other studies have conceptualized similar to us in that they viewed perceived risk as an antecedent to trust (e.g., Ho \& Cha,2013; Mayer, Davis, \& Schoorman,1995).

Gray marketers attract consumers with lower prices. However, the manufacturers often refuse to honor the warranties on gray market goods (Gudigantala \& Bicen, 2011). Therefore, a consumer may purchase a gray market product for less, but if such a product fails to meet her expectation, she bears the risk of not getting the warranty from the original manufacturer.

If a consumer assesses the subjective probability of a positive consequence (saving money by purchasing from a gray marketer) is higher than her subjective probability of a negative consequence (e.g., issues encountered in future related to warranty), she may assess the overall transaction to have a net positive consequence. In such a scenario, the consumer may develop a trusting belief in the online retailer, because the retailer's sourcing efforts, although unauthorized in some instances, have caused positive consequences for the consumer (Olivero \& Lunt, 2004).

H5: Teleological evaluation significantly influences trust in an online retailer (the lower the negative consequences one faces in an online retail environment, the higher the trust one has for the online retailer).

People have the need to understand their social surroundings to identify what, when, why, and how other people behave. However, given that people use bounded rationality, comprehending social surroundings becomes an overly complicated task (Simon, 1991). People adopt an assortment of social complexity reduction strategies to simplify the task (Gefen et al., 2003). In these circumstances, trust becomes essential and helps people adopt the belief that a trusted party has nothing to gain by cheating, and therefore, is dependable and will fulfill its commitments (Morgan \& Hunt, 1994).

Due to the social complexity embedded in an online retail environment, trust as an effective strategy allows consumers to subjectively rule out undesirable and potentially negative consequences. In his way, trust encourages consumers to engage in online purchase activity (Heijden, Verhagen, \& Creemers, 2003; Pavlou, 2003).

\section{H6: Trust positively influences purchase intention.}

\section{RESEARCH METHOD}

We employed a methodology similar to that of Hunt and Vasquez-Parraga (1993) and Vitell et al. (2001), in that we used multiple scenarios to test the research hypotheses. In particular, 2x2 betweensubjects experimental design was utilized to manipulate ethical norms (i.e., deontologically ethical situation/authorized online retailer and deontologically unethical situation/gray market online retailer) and perception of consequences (i.e., positive consequence/lower financial risk and negative 
consequence/higher financial risk). The scenarios presented to respondents were in the context of buying a Lenovo laptop from a U.S. based online retailer. We asked the respondent to play the role of a potential buyer and evaluate the information provided in the scenario for their decision-making. These scenarios were tested and refined in a pilot study using a sample of twenty-one graduate students. The four versions of these ethics scenarios are: unethical situation (gray market retailer) with positive consequences (saving money), unethical situation (gray market retailer) with negative consequences (losing warranty), ethical situation (authorized retailer) with positive consequences (special discount), and ethical situation (authorized retailer) with negative consequences (expensive product). The differences in the deontological and teleological ethicality of each scenario was tested and confirmed by an expert panel of fourteen ethics scholars who widely published and taught in the marketing ethics area. Scenarios are presented in Appendix 1.

We conducted the experiment with 114 student subjects. Given the general relevance of the consumer scenarios, this population was deemed appropriate for the situations depicted in the scenarios. The instructions in the questionnaire required respondents to place themselves as a potential buyer in one of the four scenarios. In addition, in scenarios involving gray market sourcing, we asked respondents to consider such information while making their decisions. Once they finished reading the scenario, they answered questions on measures related to perceived financial risk (used for measuring perceived consequences- teleological evaluation $)^{1}$, ethical judgment, purchase intention, and trust. The surveys were done anonymously, and the participants were given course credit as motivation to participate in the study. This study adapted and slightly modified scales from trust, purchase intention, and perceived risk literature. The measures are included in Appendix 2.

\section{Validity Assessment}

A confirmatory factor analysis was performed to assess the measurement properties of perceived risk, trust, and purchase intention. Since ethical judgment has only one indicator, it was not included in the measurement model. The results indicate a good overall model $\left(\chi^{2}(17)=48.04, p<0.001\right.$; RMSEA [root mean square error of approximation] $=.08$; GFI [Goodness of fit index] $=.90$; Bentler CFI [Comparative Fit Index] = .96) as well as strong psychometric properties of the measures. Specifically, all the standardized factor loadings are statistically significant at $\mathrm{p}<.05$, which indicates convergent validity. The factor scores ranged from .72 to .95 , with positive signs. Evidence of internal consistency stems from composite reliability (values ranging from .90 to .95), Cronbach alpha scores (values ranging from to .89 to .95), and average variance extracted (AVE; values ranging from .78 to .88). Because the square root of the AVE value for each construct is higher than the inter-construct correlations, adequate discriminant validity exists (Fornell and Larcker, 1981). Descriptive information and bivariate correlations are provided in Table 1. Psychometric properties of the measures are provided in Appendix 2. 
TABLE 1

INTER CONSTRUCT CORRELATION MATRIX

\begin{tabular}{|c|l|c|c|c|c|}
\hline & Mean (SD) & $\begin{array}{c}\text { Ethical } \\
\text { judgment }\end{array}$ & $\begin{array}{c}\text { Teleological } \\
\text { evaluation (perceived } \\
\text { risk) }\end{array}$ & Trust & $\begin{array}{c}\text { Purchase } \\
\text { intention }\end{array}$ \\
\hline $\begin{array}{c}\text { Ethical } \\
\text { judgment }\end{array}$ & $4.17(2.06)$ & 1 & & & \\
\hline $\begin{array}{c}\text { Teleological evaluation } \\
\text { (perceived risk) }\end{array}$ & $4.00(1.25)$ & 0.47 & 1 & & \\
\hline Trust & $4.07(1.74)$ & $0.79 *$ & 0.46 & 1 & \\
\hline $\begin{array}{c}\text { Purchase } \\
\text { intention }\end{array}$ & $4.47(1.52)$ & 0.37 & -0.05 & $0.56^{*}$ & 1 \\
\hline
\end{tabular}

Two tailed tests are used $* p<.05$

\section{RESULTS}

A total of 114 students participated in the experiment among which 61 were male and 53 were female. The average age of participants was 21 years with standard deviation of two years. All the subjects had experience in online shopping. The questionnaires containing scenarios were randomly assigned to subjects. Table 2 summarizes the descriptive statistics and trends for the measures used in the study. Figure 2 shows the averages of measures across the four experimental conditions.

TABLE 2

SUMMARY STATISTICS IN EACH EXPERIMENTAL CONDITION

\begin{tabular}{|c|c|c|c|c|c|c|}
\hline $\begin{array}{c}\text { Scenario } \\
(\mathrm{N}=\text { sample })\end{array}$ & $\begin{array}{c}\text { Deontological } \\
\text { Evaluation }\end{array}$ & $\begin{array}{c}\text { Teleological } \\
\text { Evaluation }\end{array}$ & $\begin{array}{c}\text { Ethical } \\
\text { Judgment } \\
\text { Mean (SD) } \\
\end{array}$ & $\begin{array}{l}\text { Perceived } \\
\text { Risk Mean } \\
\text { (SD) }\end{array}$ & $\begin{array}{l}\text { Purchase } \\
\text { Intention } \\
\text { Mean } \\
\text { (SD) } \\
\end{array}$ & $\begin{array}{c}\text { Trust Mean } \\
\text { (SD) }\end{array}$ \\
\hline $1(29)$ & Unethical & $\begin{array}{l}\text { Positive (low } \\
\text { financial risk) }\end{array}$ & $2.61(1.2)$ & $\begin{array}{c}3.68 \\
(1.14)\end{array}$ & $\begin{array}{c}4.18 \\
(1.55)\end{array}$ & $2.88(0.96)$ \\
\hline $2(28)$ & Unethical & $\begin{array}{c}\text { Negative } \\
\text { (high financial } \\
\text { risk) }\end{array}$ & $2.83(1.31)$ & $\begin{array}{c}3.98 \\
(1.07) \\
\end{array}$ & $\begin{array}{c}4.05 \\
(1.40) \\
\end{array}$ & $2.68(0.94)$ \\
\hline $3(28)$ & Ethical & $\begin{array}{l}\text { Positive (low } \\
\text { financial risk) }\end{array}$ & $5.21(1.73)$ & $3.67(1.29)$ & $\begin{array}{c}5.29 \\
(1.25)\end{array}$ & $5.03(1.59)$ \\
\hline $4(29)$ & Ethical & $\begin{array}{c}\text { Negative } \\
\text { (high financial } \\
\text { risk) }\end{array}$ & $6.14(1.16)$ & $\begin{array}{c}5.09 \\
(0.64) \\
\end{array}$ & $\begin{array}{c}4.47 \\
(1.68)\end{array}$ & $5.67(1.19)$ \\
\hline
\end{tabular}


FIGURE 2

\section{MEANS OF MEASURES ACROSS THE FOUR EXPERIMENTAL CONDITIONS}

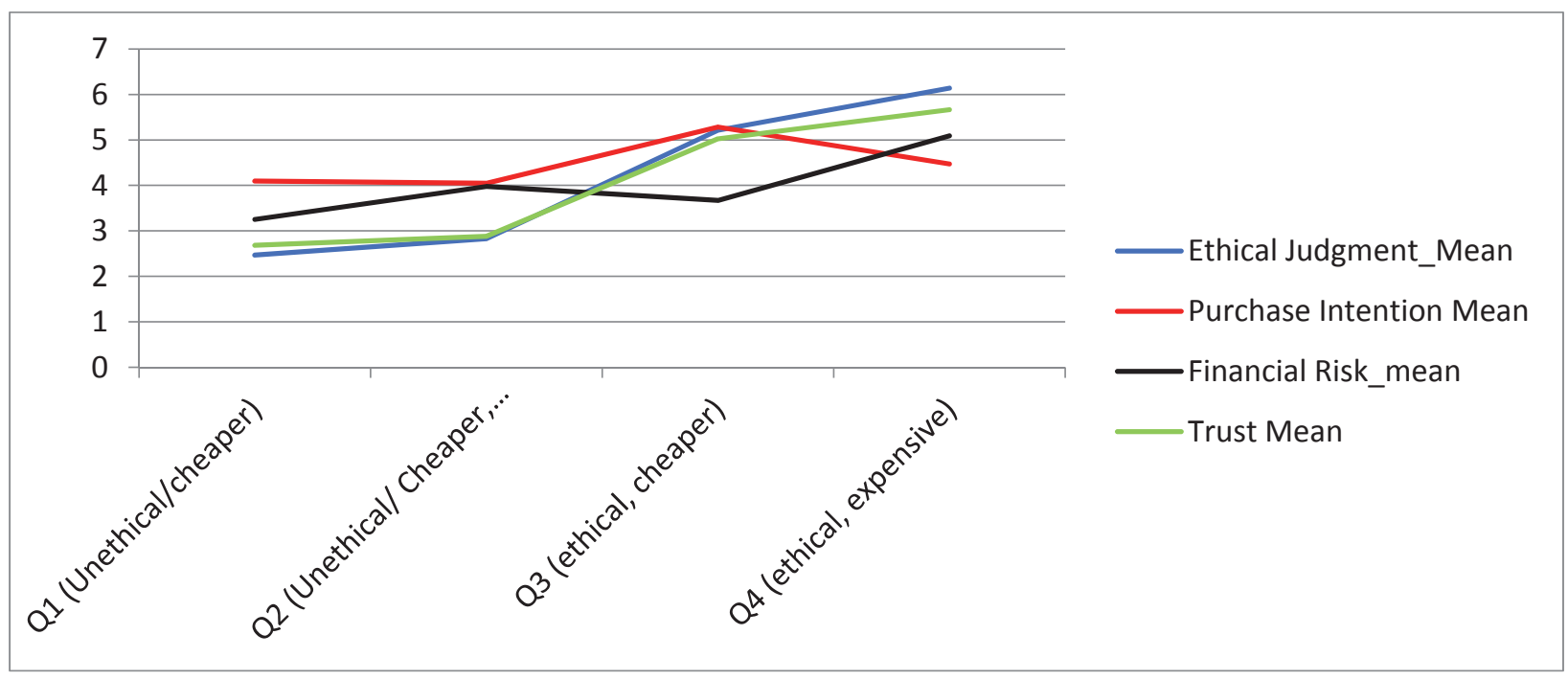

The patterns from Figure 2, for the most part, are in expected terms. The means for ethical judgments and trust are higher for ethical sourcing conditions (e.g., authorized retailer) in relation to unethical sourcing conditions (e.g., gray market retailer). Participants' perceived risk was higher for conditions where they were expected to pay more or when they anticipated issues with warranty. The purchase intention line produced an interesting result. The mean for purchase intention is expectedly low and flat for unethical sourcing conditions, spikes for 'ethical and cheaper' condition, but declines steeply for 'ethical and expensive' condition. Overall, consumers' purchase intention is higher for ethical conditions (i.e., authorized channel) than it is for unethical conditions (i.e., unauthorized gray market channel).

In Figure 1, part1, deontological and teleological evaluations are antecedents to ethical judgment $(\mathrm{H} l a$ and $\mathrm{H} 1 b)$. We tested their main effects on ethical judgment with a regression analysis. Consistent with prior research, we used deontological and teleological evaluations as dummy variables in the regression analysis to test their main effect on ethical judgment (Vitell et al, 2001). We controlled for age and gender in the regression analysis. Regression results show that both deontological evaluations $(\beta=$ .75 , $\mathrm{p}$-value $=.001)$ and teleological evaluations $(\beta=-.156, \mathrm{p}$-value $=.015)$ have significant impacts on ethical judgment. Deontological evaluations positively influence the ethical judgment; whereas teleological evaluations have a negative impact on ethical judgment. However, out of the total $58 \%$ variation explained, deontological evaluation contributed $55.6 \%$ and teleological evaluation contributed only $2.4 \%$. These results are consistent with $\mathrm{H}-\mathrm{V}$ theory's predictions and support our hypotheses, $\mathrm{H} 1 \mathrm{a}$ and $\mathrm{H} l b$.

In Figure 1, part 2, following Bagozzi and Yi (1994), we used the distribution free approach of PLS (partial least squares) structural equation modeling to test $\mathrm{H} 2, \mathrm{H} 3, \mathrm{H} 4, \mathrm{H} 5$ and $\mathrm{H} 6$, and Smart PLS 3 software is used for statistical analysis. For the PLS model testing, we used perceived financial risk measure to operationalize teleological evaluation. The other variables used are ethical judgment, trust, and purchase intention. Table 3 summarizes the estimation results.

Regarding the link between ethical judgment and purchase intention, our findings suggest that ethical judgment's influence on purchase intention is insignificant $(\beta=-.12$, t value $=.29)$ resulting in no support for $\mathrm{H} 2$. With respect to $\mathrm{H} 3$, the relationship between teleological evaluations and purchase intention, the results show a significantly negative relationship $(\gamma=-.38, \mathrm{t}$-value $=2.31)$, which means when a consumer perceives high risk, her intention to purchase decreases, supporting H3.

As for $\mathrm{H} 4$, ethical judgment is found to have a strong positive influence on trust, $(\beta=.75, \mathrm{t}$-value $=$ 2.94), which means the more a consumer believes that an online retailer's behavior is ethical, the higher 
her trust is for that retailer, supporting $\mathrm{H} 4$. As for $\mathrm{H} 5$, we found that teleological evaluation does not have a significant influence on trust, resulting in no support for $\mathrm{H} 5(\beta=.10$, t-value $=2.94)$. Finally, results show that trust has a strong positive impact on purchase intention $(\beta=.85$, $\mathrm{t}$-value $=2.52)$, resulting in strong support for H6.

TABLE 3

\section{PLS ANALYSIS RESULTS}

\begin{tabular}{|l|c|c|}
\hline Hypotheses & Coefficient value & t value \\
\hline H2: Ethical Judgment $\rightarrow$ Purchase Intention & -0.12 & 0.29 \\
\hline H3: TE (Perceived Risk) $\rightarrow$ Purchase intention & -0.38 & $2.31^{*}$ \\
\hline H4: Ethical Judgment $\rightarrow$ Trust & 0.75 & $2.94 * *$ \\
\hline H5: TE (Perceived Risk) $\rightarrow$ Trust & 0.1 & 0.51 \\
\hline H6: Trust $\rightarrow$ Purchase intention & 0.85 & $.2 .52 * *$ \\
\hline & & \\
\hline Control Variables & & 0.574 \\
\hline Age $\rightarrow$ Ethical Judgment & 0.083 & 0.936 \\
\hline Age $\rightarrow$ Trust & -0.02 & 0.864 \\
\hline Age $\rightarrow$ Purchase Intention & -0.03 & 0.882 \\
\hline Gender $\rightarrow$ Ethical Judgment & 0.47 & 0.265 \\
\hline Gender $\rightarrow$ Trust & -0.13 & 0.67 \\
\hline Gender $\rightarrow$ Purchase Intention & 0.081 & \\
\hline$T E=$ Teleological evaluations. Standardized coefficients are reported, Two tailed tests are used, ${ }^{*} p .05, * *$ \\
$<.01$
\end{tabular}

\section{FULL MEDIATION ANALYSIS}

In examining the possible key mediation effect of trust using Zhao's et al.'s (2010) procedure, we find that trust fully mediates the effect of ethical judgment on purchase intention [ßethicaljudgmentpurchaseintention $=-.12, \mathrm{t}$-value $=.29, \beta$ ethical judgment-trust $=.75, \mathrm{t}$-value $=2.94, \beta$ trust-purchaseintention $=.85, \mathrm{t}$ value $=2.52]$. Ethical judgment does not have a significant direct effect on purchase intention in the presence of trust and is thus fully mediated by trust, supporting our assertion that trust indeed plays a key role in the effect of consumers' ethical judgment on their purchase intention. As recommended by Zhao's et al.'s (2010), we also ran a Sobel test with non-parametric bootstrapping procedure with SAS, and the results show that when the direct effect of ethical judgment on purchase intention was included, the mediation effect stayed the same (e.g., the evidence for in-direct only mediation). As Table 4 shows, $b$ (PI| EJ), the total effect of ethical judgment on purchase intention, is significant; consumers who have high ethical judgment about an e-tailer also have high purchase intention from that e-tailer. The next row of the output, b (Trust| EJ), the effect of ethical judgment on trust, is also significant; consumers who have high ethical judgment about an e-tailer also have high trust in it. The third row of the output, $b$ (PI|Trust.EJ), the effect of trust on purchase intention, controls for ethical judgment. Consumers who have high trust in an e-tailer have high purchase intention from that e-tailer whether or not they have a positive ethical judgment about it. Finally, b (PI|EJ.Trust), the direct effect of ethical judgment on purchase intention, controls for trust. This effect is not significant, indicating no relationship between ethical judgment and purchase intention after controlling for trust. The evidence indicates that trust completely mediates the effect of ethical judgment on purchase intention (Preacher and Hayes 2004). 
TABLE 4

BOOSTRAP ANALYSIS RESULTS FOR MEDIATION ANALYSIS

\begin{tabular}{|l|l|l|}
\hline & \multicolumn{1}{|c|}{ Coeff. (s.e.) } & \multicolumn{1}{c|}{ T-value (p value) } \\
\hline $\mathrm{b}(\mathrm{PI} \mid \mathrm{EJ})$ & $.25(.06)$ & $3.84^{*}$ \\
\hline $\mathrm{b}($ Trust $\mid$ EJ) & $.68(.04)$ & $14.52^{*}$ \\
\hline $\mathrm{b}(\mathrm{PI} \mid$ Trust.EJ) & $.63(.12)$ & $5.38^{*}$ \\
\hline $\mathrm{b}(\mathrm{PI} \mid$ EJ.Trust) & $-.18(.10) \quad-1.8$ \\
\hline & \multicolumn{2}{|c|}{ Indirect Effects $(95 \%$ Confidence Interval) } \\
\hline $\mathrm{EJ} \longrightarrow$ Trust $\longrightarrow$ PI & \multicolumn{2}{|c|}{$(.26, .60)$} \\
\hline
\end{tabular}

EJ = Ethical Judgment $; P I=$ Purchase intention

$95 \%$ confidence interval excludes "0" which means the bootstrap mediation analysis result is significant.

\section{DISCUSSION}

The purpose of the current study was to advance our understanding of consumers' ethical decision making through: (1) identifying consumers' ethical consideration for gray market conduct in an online shopping context; (2) examining the relationship between ethical judgment and trust; (3) investigating the mediating role of trust in the dynamic relationship between ethical judgment and purchase intention; and (4) exploring the potential tradeoff between price and ethical beliefs in shaping purchase intention. The results provide promising direction in all four areas.

First, current research identified that gray market sourcing of products is associated with lower ratings of online retailers in terms of ethical judgments. Two experimental scenarios designed for an online retailer's gray market activity had a lower rating in ethical judgment than two other scenarios designed for an authorized online channel activity ( $\mu$ gray market retailer $=2.72$ vs $\mu$ authorized retailer $=5.67$ ). The number of studies exploring consumer ethics and ethical consumption has increased over the years. Though the forms of ethical practices have their own idiosyncratic nuances, our findings are consistent with the previous findings that consumers do care about firms' ethical business conduct (e.g., Creyer, 1997; Hunt \& Vitell, 2008; Thong and Yap 1998). Ethical judgments are formed both by deontological and teleological evaluations. The current study shows that compared to teleological evaluations, deontological evaluations contribute substantially more to form ethical judgment and the decision-making process.

Second, we show that firms' ethical conduct matters. Our experimental scenarios designed for online gray market activity received a much lower trust rating than the ones designed for fair channel practice of authorized dealers $(\mu$ gray market retailer $=2.78$ vs $\mu$ authorized retailer $=5.35)$. Furthermore, the PLS results show that ethical judgment positively influences trust $(\beta=.75$, t-value $=2.94)$. This finding supports the notion that as economic activities become increasingly complex as a result of the rapid technological development and the globalization of supply chains, economic systems require trust built on ethical foundations as the basis for successful relationships (Fukuyama, 1995). Companies that are considered as ethical by consumers are perceived as more trustworthy (Castaldo et al., 2009). The H-V theory of ethics does not include the concept of trust in their model. Thus, our study extends the original theory by incorporating the positive link between ethical judgment and trust.

Third, we found that trust completely mediates the effect of ethical judgment on purchase intention. The $\mathrm{H}-\mathrm{V}$ theory posits that ethical judgment has a direct influence on intention when an ethical issue is central. Our study shows that in the online gray market context, ethical judgment has an effect on purchase intention only through trust. That means a retailer's ethical business conduct is insufficient to make consumers purchase from that retailer. However, a positive judgment of ethical behavior leads to more trust to the retailer. Online retailers, therefore, should invest in strategies that strengthen consumers' trust in them. For example, web companies who are authorized dealers or sell products only from 
authorized dealers' platforms should be explicit about what it means to be an authorized channel partner (e.g., warranty issues, after-sale services) and how it reflects on their pricing policy.

We also showed that consumers' teleological evaluations have only a direct influence on their purchase intentions $(\beta=-.38$, t-value $=2.31)$. Unlike ethical judgments, whose relationship with purchase intention is only through trust, teleological evaluations don't have a significant effect on trust $(\beta=.1, \mathrm{t}$ value $=.51$ ). Teleological evaluations concern consequence-based beliefs about the relative goodness versus badness of the alternatives as perceived by the decision maker. For an individual to consider an alternative, that alternative should bring greater positive consequences in relation to the overall amount of negative consequences. For example, in our gray market case, a decision maker can evaluate the alternative of buying a laptop from a website that does business with an unauthorized dealer. Being aware of the circumstances, a decision maker can weigh his options: buying the laptop with a lower price and saving money or buying the laptop from the authorized dealer and paying the full price. Our results show that when consumers make their decision based on consequences (when perceived negative risk is outweighed by perceived benefit, such as less financial risk) their intention to purchase increases. However, their consequence-based evaluation does not have any effect on their trusting belief in the retailer. We believe this result is very significant.

Trust is considered to be the currency of long-term relationships in market-based economies. Consumers will extend their loyalty to companies only after they trust them (Morgan \& Hunt, 1994). This fact holds even stronger in a world in which customers defect at the click of a mouse and impersonal websites scour databases for even better deals. Online retailers know that acquiring customers on the Internet is expensive; unless those customers are retained and make repeated purchases, profit will remain elusive. All other attributes, including price, lag far behind.

Given that retention is only possible with companies who are trust generators selling products that deliver the best value in the rough-and-tumble world of e-commerce, it is important for retailers to earn the trust of their customers. Our results show that trust has more than two times stronger impact on purchase intention than consequence-based evaluation $(\beta=.85$ vs $\beta=-.38)$.

Finally, our results show that among four experimental conditions, trust's evaluation is highest with the ethical and high financial risk condition (mean= 5.67, $\mathrm{SD}=1.19)$, and purchase intention's evaluation is highest with the ethical and low financial risk condition (mean= 5.29, $\mathrm{SD}=1.25$ ). Compared to the unethical and low financial risk condition (mean=4.18, $\mathrm{SD}=1.55)$, consumers exhibited higher purchase intention under the ethical and high financial risk condition (mean=4.47, $\mathrm{SD}=1.68$ ) (see Figure 2). Therefore, we can conclude that when it comes to purchase intention, customers ideally prefer fair pricing with ethical business conduct. Therefore, price matters in forming the purchase intention, but not to the extent that consumers question a retailer's legitimacy of authorization and, are left in a position to compromise on their ethical beliefs.

\section{CONCLUSION}

Briefly, since gray marketers derive profits by taking advantage of authorized firms' brand reputation and market demand without investing the capital associated with establishing such reputation, and by misleading consumers about after-sale services and putting them in a potential financial risk, it is appropriate to discuss gray market activities' ethicality and resulting consumers' ethical judgments and purchase intention.

Our study explores consumers' ethical judgment about gray marketers, and whether this judgment has an impact on their online purchasing behavior. To our knowledge, this is the first empirical study that explores these relationships in an online purchasing context. Drawing on the H-V theory of ethics, we found that consumers' ethical judgment is mostly influenced by deontological norms, representing the inherent rightness and wrongness of a behavior. Compared to the teleological evaluations, deontological evaluations contribute five times more to the ethical judgment process. As for the question of, "do their ethical judgments matter for their online purchase intention?" we found that ethical judgment has a strong positive influence on purchase intention, but only through trust. In our extended model tested in the gray 
market context, the results show that trust fully mediates that relationship, which means firms that are considered as ethical by consumers are perceived as more trustworthy, which leads to higher purchase intention.

Our results are controlled for age and gender and show no significant difference. Attracting customers with low prices at any cost instead of building trust and developing relationships with them may create benefits in the short run for gray marketers, but over the long run it is likely to erode their customer base because of the unfair and unethical nature of their business conduct and low trust related to that. Consumer trust requires ethical business conduct.

The current study is not without its limitations. First, in any study of ethics there is always an element of social desirability associated with consumer responses. We have not measured or controlled for the effects of social desirability. Second, the study makes the assumption that consumers are aware of the sourcing practices of online retailers. This may not be true in a majority of circumstances, although consumer awareness of sourcing activities of firms is generally on the rise. Finally, the current study only included financial risk when conceptualizing teleological evaluations. There may be other types of risks such as performance risks, psychological risks, and online payment risks. Future studies may consider some of these additional risks.

\section{ACKNOWLEDGMENT}

The authors would like to thank the Dundon-Berchtold research initiative in ethics at the University of Portland for supporting this research.

\section{ENDNOTE}

1. In part 1 of the model (Figure 1), teleological evaluation is operationalized as a dummy variable. In part 2 of the model, teleological evaluation is operationalized with a perceived risk measure. Expert panel while evaluating the differences in the teleological ethicality of the scenarios also evaluated the appropriateness of the perceived risk measure for teleological evaluation. There was a strong consensus on the appropriateness of the measure. Further, with the data from 114 subjects, we ran a t-test to see whether there is a significant difference between perceived positive consequences (low perceived financial risk) and perceived negative consequences (high perceived financial risk) scenarios. Mean for the perceived negative consequences scenarios, scenarios \#2 and \#4, was 4.75 with $\mathrm{SD}=1.8$. Mean for the perceived positive consequences, Scenarios \#1 and \#3, was 3.4 with $\mathrm{SD}=1.39$. The t-test results showed that the difference was statistically significant ( $\mathrm{t}-\mathrm{stat}=-5.05, \mathrm{p}$ value $=0.001$ ). In addition, the dummy variable regression using perceived consequences as independent variable and perceive financial risk as dependent variable is highly significant $(\mathrm{F}=19.7, \mathrm{p}<0.0001)$. These results indicate perceived financial risk is a satisfactory proxy measure for teleological evaluation (perceived consequences). 


\section{REFERENCES}

AGMA. (2008). Three keys to effectively addressing the unauthorized reseller market. The Alliance for Gray Market and Counterfeit Abatement. Retrieved January 17, 2019, from https://www.agmaglobal.org/uploads/news\%20releases/current/2008/Unauthorized\%20Market\% 20EMEA\%20FINAL\%204-8-08_sw.pdf

AGMA. (2016). Gray markets: An evolving concern. Retrieved January 17, 2019, from http://www.agmaglobal.org/cms/uploads/whitePapers/2-25-16\%20Gray\%20Market\%20Survey2015\%20KPMG\%20AGMA.pdf

Ahmadi, R., Iravani, F., \& Mamani, H. (2015). Coping with gray markets: The impact of market conditions and product characteristics. Production and Operations Management, 24(5), 762-777.

Altug, M. S. (2017). The dynamics of domestic gray markets and its impact on supply chains. Production and Operations Management, 26(3), 525-541.

Antia, K. D., Bergen, M.E., Dutta, S., \& Fisher, R. (2006). How does enforcement deter gray market incidence? Journal of Marketing, 70(1), 92-106.

Bagozzi, R. P., \& Yi, Y. (1994). Advanced topics in structural equation models. In Advanced Methods of Marketing Research. (ed). Bagozzi, R.P. Cambridge, MA: Blackwell, 1-52.

Bauer, R.A. (1960). Consumer behavior as risk taking. In: Hancock, R.S., Ed., Dynamic Marketing for a Changing World, Proceedings of the 43rd. Conference of the American Marketing Association, 389-398.

Belk, R., Devinney, T., \& Eckhardt, G. (2005). Consumer ethics across cultures. Consumption Markets \& Culture, 8(3), 275-289.

Berman, B., \& Dong, M. (2016). Gray markets: past, present, and future. The International Review of Retail, Distribution, and Consumer Research, 26(1), 95-111.

Caldwell, C., \& Clapham, S.E. (2003). Organizational trustworthiness: an international perspective. Journal of Business Ethics, 47(4), 349-364.

Carrigan, M., \& Attalla, A. (2001). The myth of the ethical consumer-do ethics matter in purchase behavior? Journal of Consumer Marketing, 18(7), 560-578.

Castaldo, S., Perrini, F., Misani, N., \& Tencati, A. (2009). The missing link between corporate social responsibility and consumer trust: The case of fair trade products. Journal of Business Ethics, 84(1), 1-15.

Chen, H. (2007). Gray marketing and its impact on brand equity. Journal of Product and Brand Management, 16(4), 247-256.

Creyer, E. H. (1997). The influence of firm behavior on purchase intention: do consumers really care about business ethics? Journal of Consumer Marketing, 14(6), 421-432.

Fornell, C., \& Larcker, D.F. (1981). Evaluating structural equation models with unobservable variables and measurement error. Journal of Marketing Research, 18(1), 39-50.

Friedman, L. M. (1998). Business and legal strategies for combating gray-market imports. International Law, 32(1), 27-50.

Fukuyama, F. (1995). Trust: the social virtues and the creation of prosperity. New York: Free Press.

Galstian, A. G. (2000). Protecting against the gray market in the new economy. International \& Comprehensive Law Review, 22, 507-532.

Gefen, D., Karahanna, E., \& Straub, D.W. (2003). Trust and TAM in online shopping: an integrated model. MIS Quarterly, 27(1), 51-90.

Gudigantala, N., \& Bicen, P. (2011). Gray market for information technology (IT) products: status, implications, and strategies to address the IT gray market threat. Communications of the Association for Information Systems, 29(10). Retrieved from http://aisel.aisnet.org/cais/vol29/iss1/10

Gullett, J., Do, L., Canuto-Carranco, M., Brister, M., Turner, S., \& Caldwell, C. (2009). The buyersupplier relationship: an integrative model of ethics and trust. Journal of Business Ethics, 90, 329-341. 
Heijden, H., Verhagen, T., \& Creemers, M. (2003). Understanding online purchase intentions: contributions from technology and trust perspectives. European Journal of Information Systems, 12(1), 41-48.

Hong, I.B., \& Cha, H. (2013). The mediating role of consumer trust in an online merchant in predicting purchase intention. International Journal of Information Management, 33(6),927-939.

Huang, J. (2004). Consumer attitude towards gray market goods. International Marketing Review, 21(6), 598-614.

Hunt, S. D., \& Vasquez-Parraga, A.A. (1993). Organizational consequences, marketing ethics, and salesforce supervision. Journal of Marketing Research, 30(1), 78-90.

Hunt, S. D., \& Vitell, S. (1986). A general theory of marketing ethics. Journal of Macromarketing, 6(1), 5-16.

Hunt, S. D., \& Vitell, S.J. (2006). The general theory of marketing ethics: A revision and three questions. Journal of Macromarketing, 26(2), 143-153.

Iravani, F., Dasu, S., \& Ahmadi, R. (2016). Beyond price mechanisms: how much can service help manage the competition from gray markets? European Journal of Operational Research, 252(3), 789-800.

Keen, P. G.W. (2000). Ensuring e-trust. Computer World, 34(11), 46.

Koltrowitz, S. (2017). Gray market has become a necessary evil for luxury watchmakers. Technology News. Retrieved January 17, 2019, from http://www.reuters.com/article/us-swiss-watches-greymarket-idUSKBN17E2E8

Mathur, L. (1995). The impact of international gray marketing on consumers and firms. Journal of Euromarketing, 4(2), 39-59.

Mittal, S. (2017). Legal feasibility of the concept of international exhaustion in Intellectual Property Law. Retrieved from SSRN: https://ssrn.com/abstract $=2975643$

Morgan, R., \& Hunt, S.D. (1994). The commitment-trust theory of relationship marketing. Journal of Marketing, 58(3), 20-38.

Myers, M. B., \& Griffith, D.A. (1999). Strategies for combating gray market activity. Business Horizon, 42(6), 2-8.

Olivero, N., \& Lunt, P. (2004). Privacy versus willingness to disclose in e-commerce exchanges: the effect of risk awareness on the relative role of trust and control. Journal of Economic Psychology, 25(2), 243-262.

Pavlou, P. A. (2003). Consumer acceptance of electronic commerce: integrating trust and risk with the technology acceptance model. International Journal of Electronic Commerce, 7(3),101-134.

Preacher, K. J., \& Hayes, A.F. (2004). SPSS and SAS procedures for estimating indirect effects in simple mediation models. Behavior Research Methods, Instruments, and Computers, 36(4), 717-31.

Simon, H. (1991). Organizations and markets. Journal of Economic Perspectives, 5(2), 25-44.

Stone, R. N., \& Gronhaug, K. (1993). Perceived risk: further considerations for the marketing discipline. European Journal of Marketing, 27(3), 39-50.

Tan, B. (2002). Understanding consumer ethical decision making with respect to purchase of pirated software. Journal of Consumer Marketing, 19(2), 96-111.

Tan, S. J., Lim, G.H., \& Khai, S. L. (1997). Strategic responses to parallel importing. Journal of Global Marketing, 10(4), $45-66$

Thygersen, J. (1999). The ethical consumer: moral norms and packaging choice. Journal of Consumer Policy, 22(4), 439-460.

Thong, J. Y.L., \& Yap, C. (1998). Testing an ethical decision making theory: the case of softlifting. Journal of Management Information Systems, 15(1), 213-237.

Vitell, S., Singhapakdi, A., \& Thomas, J. (2001). Consumer ethics: an application and empirical testing of the Hunt-Vitell theory of ethics. Journal of Consumer Marketing, 18(2), 153-178.

Zhao, X., JLynch, J. G., \& Chen, Q. (2010). Reconsidering Baron and Kenny: myths and truths about mediation analysis. Journal of Consumer Research, 37(2), 197-206. 


\section{APPENDIX 1 \\ SCENARIOS}

\begin{tabular}{|c|c|c|}
\hline & $\begin{array}{l}\text { Deontologically unethical condition (seller } \\
\text { sources from gray market) }\end{array}$ & $\begin{array}{l}\text { Deontologically ethical condition (seller } \\
\text { sources from authorized distribution } \\
\text { channel) }\end{array}$ \\
\hline $\begin{array}{l}\text { Positive } \\
\text { Consequence } \\
\text { for Customer } \\
\text { (low financial } \\
\text { risk) }\end{array}$ & $\begin{array}{l}\text { Scenario 1: } \\
\text { ElectronicsForYou.com, a U.S.-based retail } \\
\text { e-commerce company recently had an } \\
\text { opportunity to import a large number of } \\
\text { genuine Lenovo laptops from a wholesaler } \\
\text { in China. The Chinese wholesaler is not } \\
\text { authorized by Lenovo to sell to U.S.-based } \\
\text { companies. Normally in the U.S., this } \\
\text { laptop is bought at } \$ 1100 \text { by } \\
\text { ElectronicsForYou.com from authorized } \\
\text { U.S. wholesalers and sold at } \$ 1200 \text {, but } \\
\text { ElectronicsForYou.com acquired the } \\
\text { laptops for } \$ 800 \text { apiece from the Chinese } \\
\text { wholesaler in spite of knowing the } \\
\text { unauthorized nature of the transaction. } \\
\text { ElectronicsForYou.com now sells these } \\
\text { genuine Lenovo laptops at } \$ 1000 \text { on their } \\
\text { website whereas the nearest rival sells the } \\
\text { same for } \$ 1200 \text {. Therefore, a consumer } \\
\text { who buys a laptop from } \\
\text { ElectronicsForYou.com not only gets a } \\
\text { genuine Lenovo laptop but also gets it for } \\
\$ 200 \text { cheaper than the next best competitor } \\
\text { on the Internet. }\end{array}$ & $\begin{array}{l}\text { Scenario 3: } \\
\text { ElectronicsForYou.com, a U.S.-based } \\
\text { retail e-commerce company recently } \\
\text { had an opportunity to import a large } \\
\text { number of genuine Lenovo laptops from } \\
\text { a wholesaler in China for only } \$ 800 \text { per } \\
\text { laptop; whereas, the U.S-based } \\
\text { authorized wholesaler sells the same for } \\
\$ 1100 \text {. However, the Chinese } \\
\text { wholesaler is not authorized by Lenovo } \\
\text { to sell to U.S.-based companies. } \\
\text { ElectronicsForYou.com decided to } \\
\text { decline the purchase offer from the } \\
\text { Chinese wholesaler as it is an improper } \\
\text { transaction. When Lenovo came to } \\
\text { learn about ElectronicsForYou.com's } \\
\text { decision, they appreciated the gesture } \\
\text { and offered a large stock of Lenovo } \\
\text { laptops for only } \$ 800 \text { per laptop. } \\
\text { ElectronicsForYou.com now sells these } \\
\text { genuine Lenovo laptops at } \$ 1000 \text { on } \\
\text { their website whereas the nearest rival } \\
\text { sells the same for } \$ 1200 \text {. Therefore, a } \\
\text { consumer who buys a laptop from } \\
\text { ElectronicsForYou.com not only gets a } \\
\text { genuine Lenovo laptop but also gets it } \\
\text { for } \$ 200 \text { cheaper than the next best } \\
\text { competitor on the Internet. }\end{array}$ \\
\hline $\begin{array}{l}\text { Negative } \\
\text { Consequence } \\
\text { for Customer } \\
\text { (high } \\
\text { financial risk) }\end{array}$ & $\begin{array}{l}\text { Scenario 2: } \\
\text { ElectronicsForYou.com, a U.S.-based retail } \\
\text { e-commerce company recently had an } \\
\text { opportunity to import a large number of } \\
\text { genuine Lenovo laptops from a wholesaler } \\
\text { in China. The Chinese wholesaler is not } \\
\text { authorized by Lenovo to sell to U.S.-based } \\
\text { companies. Normally, this laptop is bought } \\
\text { at } \$ 1100 \text { from the authorized U.S. } \\
\text { wholesaler and sold at } \$ 1200 \text {, but } \\
\text { ElectronicsForYou.com acquired the } \\
\text { laptops for } \$ 800 \text { apiece from the Chinese } \\
\text { wholesaler in spite of knowing the } \\
\text { unauthorized nature of the transaction. } \\
\text { ElectronicsForYou.com now sells genuine } \\
\text { Lenovo laptops at } \$ 1000 \text { on their website } \\
\text { whereas the nearest rival sells the same for }\end{array}$ & $\begin{array}{l}\text { Scenario 4: } \\
\text { ElectronicsForYou.com, a U.S.-based } \\
\text { retail e-commerce company recently } \\
\text { had an opportunity to import a large } \\
\text { number of genuine Lenovo laptops from } \\
\text { a wholesaler in China for only } \$ 800 \text { per } \\
\text { laptop; whereas, the U.S-based } \\
\text { authorized wholesaler sells the same for } \\
\$ 1100 \text {. However, the Chinese } \\
\text { wholesaler is not authorized by Lenovo } \\
\text { to sell to U.S.-based companies. } \\
\text { ElectronicsForYou.com decided that it } \\
\text { is an improper transaction and declined } \\
\text { to purchase from the Chinese } \\
\text { wholesaler. However, a local U.S.- } \\
\text { based competitor of } \\
\text { ElectronicsForYou.com purchased the }\end{array}$ \\
\hline
\end{tabular}




\begin{tabular}{|l|l|l|}
\hline $\begin{array}{l}\text { \$1200. However, Lenovo discovered this } \\
\text { unauthorized transaction through their } \\
\text { audits and decided to decline any warranty } \\
\text { on this laptop to customers who purchased } \\
\text { it on ElectronicsForYou.com. Therefore, a } \\
\text { consumer who buys a laptop from } \\
\text { ElectronicsForYou.com not only gets a } \\
\text { genuine Lenovo laptop but also gets it for } \\
\text { \$200 cheaper than the next best competitor } \\
\text { on the Internet. However, once a consumer } \\
\text { purchases the laptop, they may run into } \\
\text { warranty issues with Lenovo in case of any } \\
\text { problems with the laptop in future. }\end{array}$ & $\begin{array}{l}\text { ElectronicsForYou.com sells the same } \\
\text { for \$1200 apiece. Therefore, a } \\
\text { consumer who buys a laptop from } \\
\text { ElectronicsForYou.com gets a genuine } \\
\text { Lenovo laptop but pays \$200 more than } \\
\text { the next best competitor on the Internet. }\end{array}$ \\
\hline
\end{tabular}




\section{APPENDIX 2 \\ MEASURES}

Ethical Judgment (measured on 1-7 Likert Scale, 1=Very unethical, 7=very ethical)

Source: Shelby, D. H., \& Vasquez-Parraga, A. Z. (1993)

- I feel the sourcing behavior of ElectronicsForYou.com is........

(note: "sourcing" refers to the process used by ElectronicsForYou.com to acquire the laptops to be sold to the end consumers)

Perceived Financial Risk (measured on 1-7 Likert Scale, 1=strongly disagree, $7=$ strongly agree)

Source: Vehagen, Meents, \& Tan (2006).

Composite Reliability $(C R)=.89 ;$ Average Variance Extracted $(A V E)=.81$ Cronbach alpha: .89

- If I were to purchase Lenovo laptop from ElectronicsForYou.com, I would be concerned that the laptop in this website may be more expensive than products in a different place

- If I were to purchase Lenovo laptop from ElectronicsForYou.com, I would be concerned that I might be able to buy the same product at a different place at a lower price than in ElectronicsForYou.com

- If I were to purchase Lenovo laptop from ElectronicsForYou.com, I may suffer monetary loss due to sales fraud *

Trust (measured on 1-7 Likert Scale, 1=strongly disagree, $7=$ strongly agree)

Source: Hong \& Cha (2013)

Composite Reliability $(C R)=.95$; Average Variance Extracted $(A V E)=.88$ Cronbach alpha: .95

- I believe ElectronicsForYou.com is dependable

- I believe ElectronicsForYou.com is reliable

- I believe ElectronicsForYou.com is honest

- I believe ElectronicsForYou.com is trustworthy*

Purchase Intention (measured on 1-7 Likert Scale, 1=strongly disagree, $7=$ strongly agree)

Source: Vehagen, Meents, \& Tan (2006).

Composite Reliability $(C R)=.91$; Average Variance Extracted $(A V E)=.78$ Cronbach alpha: .91

- If I needed a Lenovo laptop now, I would consider purchasing it from ElectronicsForYou.com

- If I needed a Lenovo laptop in the near future, I would purchase it from ElectronicsForYou.com

- I would recommend ElectronicsForYou.com to a friend

* indicates deleted items because of low factor loadings. 